\title{
A Survey of the Story Elements of Isekai Manga
}

\section{Dr. Paul S. Price}

\author{
Volume 2, Pages 57-91
}

\begin{abstract}
This paper presents a survey of the story elements in isekai (other world) manga. The large number of available isekai manga series allows the use of a survey to investigate patterns in story elements. These patterns can be used to generate hypotheses about relationships between story elements, authors' intent, and readers' interests. The paper begins with a review of the characteristics of isekai manga stories and places the stories into existing speculative fiction ontologies. A brief history of isekai manga and their relationships to roleplaying computer and tabletop games is provided. Finally, descriptions of the survey framework, instrument and results are presented. The survey includes data on 746 manga series identified as isekai manga by publishers or fans. The series are divided into four types (portal-quest, immersive, intrusion, and liminal). A detailed survey was performed on the 427 series identified as "portal-quest" stories (the most common type of isekai stories). The survey results are captured in a database of story elements that is organized based on plot points dictated by the form of the portal-quest stories. The survey found that the majority of the manga series are inspired by first-person shônen and otome computer games. The characteristics of the stories vary with the gender and age of the protagonists (here taken as surrogates for the gender and age of the stories' target audiences) and this variation allows the generation of hypotheses on the motivations and interests of the different reader demographics and how they are satisfied by the stories. A database and a data dictionary are provided as ancillary files and could be used to perform additional analyses of isekai manga.
\end{abstract}

Keywords: isekai, portal-quest, manga, database, fantasy

\section{Author Bio:}

Dr. Price has had a forty-five-year career as a risk assessor, evaluating hazards posed by exposure to chemicals. He has published more than eighty papers and book chapters on toxicology and exposure assessment. His interested in anime and manga is driven by the ability of these literary forms to explore issues related to society and technology.

This work is licensed under a Creative Commons Attribution-NonCommercial 2.0 


\section{Introduction}

Isekai (other world) stories is a type of manga popular in Japan and the United States. The degree of popularity of isekai manga can be seen in the number of series listed at Anime-Planet, a website that tracks English translations of manga and anime. This site has information on 605 manga series and 102 anime series and movies that it identifies as isekai. The site reports that 385 isekai manga series were published in the years 2017 to 2019 , or roughly one new series every three days (Figure 1 ). ${ }^{1} \mathrm{~A}$ similar peak in the number of isekai-based anime occurred over the same period with the broadcast of 39 isekai series or roughly one new series a month. ${ }^{2}$

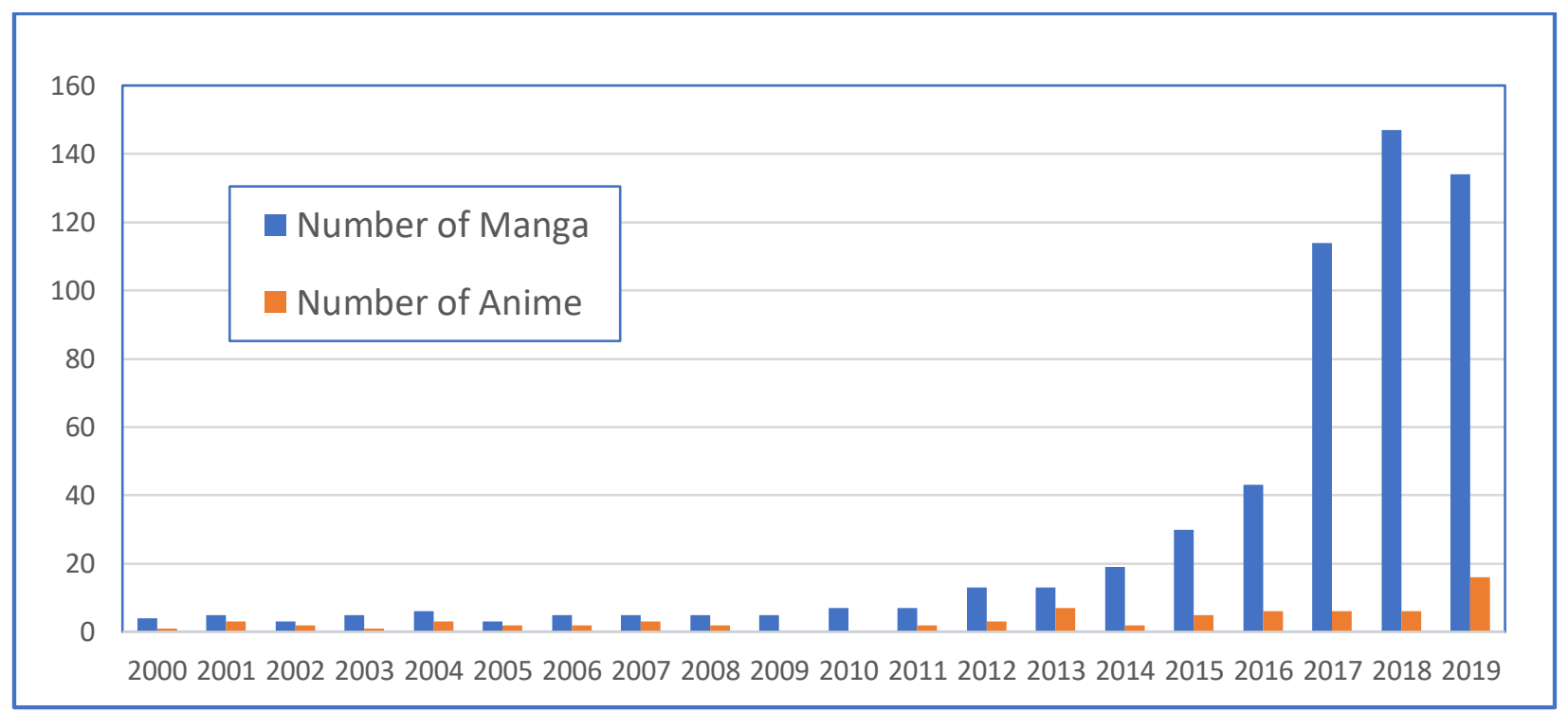

Figure 1: Number of isekai manga and anime series released in the years 2000 to 2019 as reported by the internet site Anime-Planet ${ }^{3}$

This paper presents the results of a survey of isekai manga that attempts to quantify the occurrence of certain story elements in isekai stories. The paper begins with a review of the concept of isekai in literature. This review consists of a discussion of the 
role of "other worlds" in literature, an examination of how isekai manga are categorized in existing ontologies of speculative fiction, and a discussion of the impact of role-playing games on isekai manga. The survey instrument, data frame, and results are then presented. The paper uses the results of the survey to explore two issues. First, are isekai stories an example of Azuma's database narratives?4 Specifically, can the key elements of the isekai stories be captured in a database that forms the stories' "grand nonnarrative"? Second, can a survey identify relationships between story elements that provides insights on the interests of readers and how they are serviced by authors and editors? As a demonstration of how the survey could be used to study these relationships, this paper explores the specific question of whether the age and gender of a story's protagonists prior to entering the isekai are associated with differences in story elements.

\section{Other world stories and isekai manga}

"Other world" stories include any story that involves a setting that is outside the "real" or "everyday" world. Other worlds can be defined spatially (a different land or planet), temporally (a past or future age), or as simply being different. As a result, other world stories include historical fiction; travel stories (including stories related to vacations, pilgrimages, or migrations); military stories; and speculative fiction. Japanese classical literature includes examples of stories involving other worlds such as Ryūgū-jô or the island of Hôrai. Many of the classics of Western literature are also other world stories, including The Odyssey, Robinson Crusoe, Gulliver's Travels, Candide, Alice in Wonderland, and A Connecticut Yankee in King Arthur's Court. Because other world stories are only defined by setting, they are not limited to any specific topic and can 
include stories from diverse genres such as adventure, romance, erotica, horror, mystery, humor, and satire.

Stories set in other worlds play a particularly important role in speculative fiction. Speculative fiction greatly values well-crafted and internally consistent fictional worlds. 5 Western science fiction often has individuals travel to remote places on the earth, outer space, other planets, or locations defined using extra dimensions. ${ }^{6}$ Western fantasy stories also occur in other worlds (e.g., Neverland, Oz, Middle Earth, and Narnia) that are not defined spatially or temporally (as in science fiction) but in terms of differences in culture, rules, and inhabitants.

While other world stories can be diverse, manga series identified by publishers, reviewers, and fans as isekai fall into the genre of speculative fiction. While all speculative fiction could be considered to be other world stories, the term isekai is only applied to a subcategory of speculative fiction stories in manga, anime, and light novels. The use of isekai as a subcategory is also relatively recent. The exact date of the initial use of isekai for this purpose is unclear, but trends in the use of terms in Google searches (Figure 2) indicate that such use of isekai as a story type was rare and sporadic before $2013 .{ }^{7} \mathrm{After}$ 2013 the use of the term rapidly increased. Following the widespread use of the term, certain earlier light novels, manga, and anime were retroactively defined as isekai. To understand what is meant by isekai manga and how isekai stories differ from other types of speculative fiction, it is useful to review how isekai stories fit into existing ontologies of fantasy and to consider the impacts of roleplaying games on the manga at or just before 2013. 


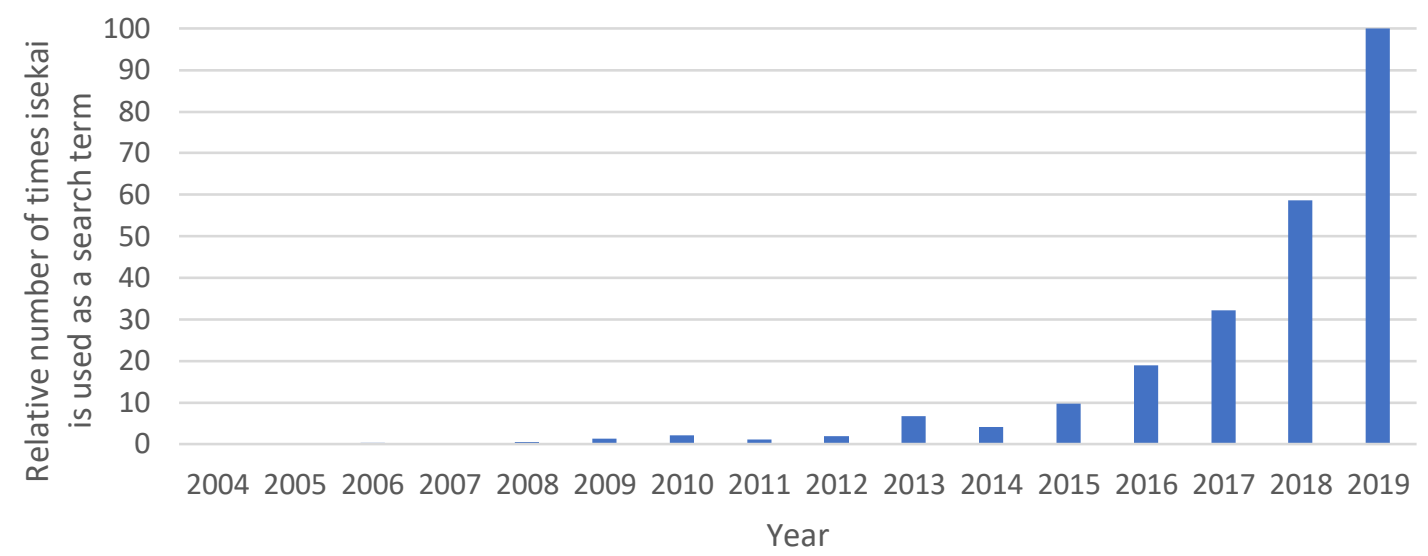

Figure 2. The frequency of the use of isekai as a Google search term for a literary genre in the years 2004 to 2019 normalized to the frequency of use in 2019. The frequency of use in 2019 is arbitrarily set to 100. (Google Trends) ${ }^{8}$

\section{Isekai and fantasy literature ontologies}

There are multiple systems for categorizing fantasy literature. Stories have been divided into "high" and "low" fantasy. ${ }^{9}$ Stories set in the real world but have some fantastical element are considered to be low fantasies and stories that occur in worlds that are separate from the real world are considered high fantasies). By definition, isekai manga are categorized as high fantasy since they deal with other worlds. Isekai stories also have characters, events, and processes that greatly differ from the real world. Tzvetan Todorov divides fantasy into three categories: the uncanny, where events may seem supernatural but are found to be due to natural processes; the marvelous, where the events are, in fact, supernatural; and the fantastic, where the nature of the events are not resolved. Isekai stories are assigned to the category of the marvelous. ${ }^{10}$ From the point in the story where the protagonist first sees a goblin in a forest or sees house servants in a noblewoman's seventeenth-century sitting room, there is no doubt in the reader's mind 
that the protagonist is experiencing something different from the real world of modern Japan.

Farah Mendlesohn's framework for organizing fantasy is particularly useful for studying isekai stories. ${ }^{11}$ She proposes dividing fantasy stories into four types (portalquest, immersive, intrusion, and liminal) that are defined in terms of a portal that both separates and connects the marvelous other world and the real world (Figure 3). The following text illustrates the four types using examples from fantasy anime and isekai manga. In portal-quest stories, the protagonist encounters the marvelous in an isekai that is entered by passing through a portal. The protagonist may or may not cross back through the portal, but the marvelous does not enter the real world. The anime movie Spirited Away (2001, Sen to Chihiro no kamikakushi) is a portal quest story, as are the isekai manga series Death March to the Parallel World Rhapsody (2014, Desu māchi kara hajimaru isekai kyōsōkyoku) and In Another World with My Smartphone (2017, Isekai wa sumātofon to tomo ni). In immersive stories, there is no portal between the marvelous and the real world, and all events occur in a marvelous world. Kiki's Delivery Service (1989, Majo no Takkyūbin) is an immersive fantasy, as are the isekai fantasy franchises Record of the Lodoss War (1988 - present, Rōdosu-tō senki), and Slayers (1989-2012, Sureiyāzu). In intrusion stories, the marvelous enters the real world from the isekai resulting in changes that must be negotiated. The Tale of Princess Kaguya (2013, Kaguya-hime no monogatari) and the isekai manga series The Devil Is a Part-Timer! (2012, Hataraku maousama!) are intrusion stories. In liminal stories, the portal becomes a liminal space where reality and the marvelous isekai mix. Such stories can also fall into Todorov's category of the fantastic. ${ }^{12}$ My Neighbor Totoro, (1988, Tonari no totoro) 
presents a rural home and nearby forest as a liminal space where the marvelous is interwoven with the real world. Isekai manga in this category include the series Alternate world bar "Nobu" (2012, Isekai Izakaya "Nobu") and Restaurant to another world (2012, Isekai Shokudou) where restaurants form liminal spaces in which characters from the real world and isekai interact.

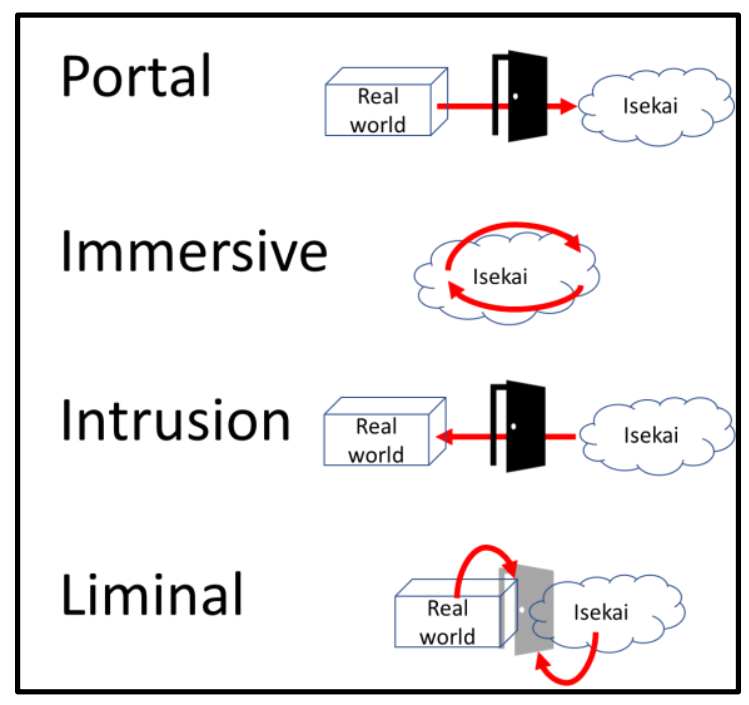

Figure 3. Mendlesohn's types of fantasy applied to isekai ${ }^{13}$

\section{Isekai manga, roleplaying games, and standard gamic worlds}

The recent growth in the number of isekai manga is linked to the advent of computer roleplaying games and the "standard" worlds they create. Stories prior to 2010 that have been retroactively identified as isekai tend to have the protagonist enter the isekai and fulfill a quest that meets the needs of the characters in the isekai (e.g., Inuyasha: A Feudal Fairy Tale, (1996, Inuyasha: sengoku otogi kassen) and Magic Knight Rayearth, (1993, Majikku naito reiāsu)) or allows the protagonist and their companions to return to the real world (e.g., El-Hazard, (1995, Shinpi no sekai eru 
hazādo)), or both (e.g., The Vision of Escaflowne (1994, Tenkū no Esukafurōne)). But most of these earlier stories do not include elements from roleplaying games. The few manga that do reference games tend to be literary expressions of the storylines of the computer games (The Legend of Zelda - Ocarina of Time, (2000, Zelda no densetsu - toki no ocarina), and MuvLuv (2003)). These manga series were created as part of gamic media mixes, a process of publishing manga and anime versions of game plots that began in the 1980 s. ${ }^{14}$ In contrast, the majority of isekai manga after 2010 are set in worlds based on different types of roleplaying games (shônen action games, otome romance games, dating sims, and battle royales). The most important of these are the shônen action games and otome romance games.

\section{Shônen roleplaying games}

In the years 2010 to 2012, three portal-quest isekai manga series began publication; Sword Art Online (2010, Sōdo àto onrain), Log Horizons (2012, Rogu horaizun), and This world is a game, but only I know (2012, Kono Sekai ga Game dato Ore dake ga Shitte Iru). ${ }^{15}$ In each of these series a young male protagonist enters a roleplaying game that they regularly play. But instead of carrying out the role of a player of the game, the protagonists initiate and participate in new stories that differ from the plots of the games. These three series are the beginning of a wave of gamic shônen isekai manga that has come to dominate isekai manga. The rise of isekai as a search term for a literary genre that occurred at this time suggests that these series, along with the large number of light novels with similar game-related plots, established what was initially meant by isekai manga. 
The shônen roleplaying games developed from tabletop games such as Dungeons and Dragons. ${ }^{16}$ These games in turn drew on elements in numerous works of Western speculative fiction, religion, and myth. ${ }^{17}$ The standard shônen world consists of humans (knights, adventurers, priests, and wizards), humanoids (elves, dwarves, and fairies), monsters (goblins, dragons, and werewolves), and certain environments (walled cities, forests, castles, and dungeons). In the shônen world magic exists alongside limited technology. Visually the world appears to be a vaguely European late medieval culture (Figure 4), a style with a long history in anime and manga. ${ }^{18}$ The goal of the player in these games is to carry out tasks (small quests) that allow the player to grow and acquire new skills. The game ends when the player completes a large and difficult final quest.

The real-world protagonists' ability in the isekai manga to act outside of this rigidly defined role (fight, win, grow, and repeat) occurs because they understand that the isekai is a game whose rules they can choose to either follow or not follow. This ability results in novel alternatives to the standard plots of the gamic manga. The protagonist can choose any number of goals from altruism, to seeking a restful quiet life, to a life of vengeance and antisocial behavior. In games, a sharp distinction is made between player and nonplayer characters since non-player characters are limited to responding to player's cues. In the manga, non-player characters can be active agents in the story taking roles of teachers, students, team members, servants, lovers, and family. The stories also include activities outside of those required by the game. These additions include mundane activities and attending settings such as eating (restaurants, kitchens, taverns, and markets), sleeping (inns, hotels, and homes), bathing (bathrooms and onsen), shopping (stores, bazaars, and fairs), and farming (fields, barns, and stables). The net result of these 
changes is an enrichment of the gamic world providing new objects, individuals, plots, and tropes.

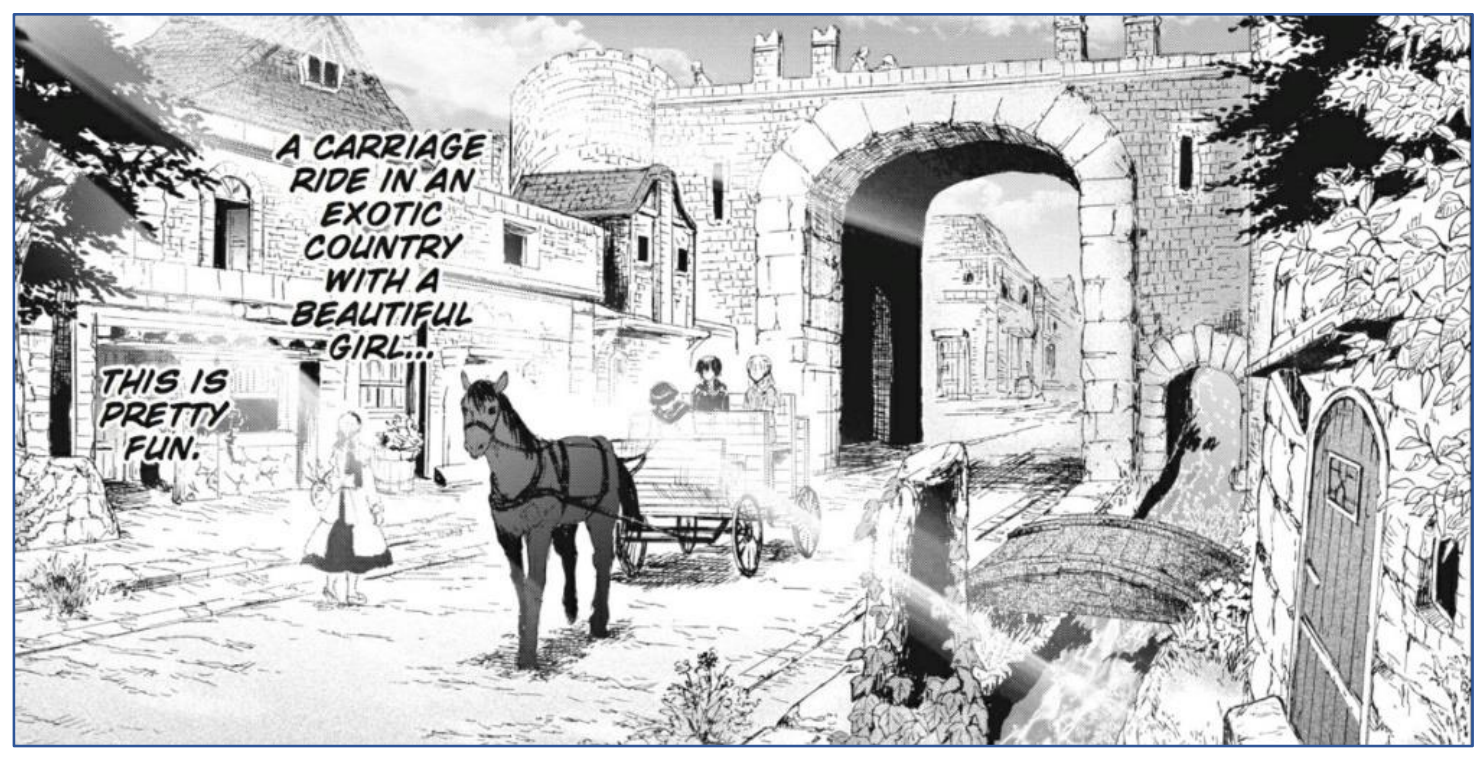

Figure 4. Cityscape in a standard shônen gamic world from Death March to the Parallel World Rhapsody (2014)

\section{Otome games}

In 2015, the first of an entirely different type of gamic isekai story was published, Accomplishments of a Duke's Daughter (Koushaku Reijo No Konomi). These manga are based on first person shōjo or josei otome games. In these games, a player guides a female protagonist in the exploration of romantic relationships with male love interests. The games use visual novel or dating simulation formats that rely on text to provide information to the player and to advance game play. The goal of the games is for the player to make choices for the protagonist that allow the protagonist to capture the love of a male target. A single game may have multiple romantic targets. Such games must be played multiple times to allow the protagonist to conquer each target. In these games, players 
are opposed by noncharacter players who compete for the targets. Characters, both player and nonplayers, have back stories that are often more extensive and emotionally rich then in the shônen isekai stories. Otome games are set in the upper levels of a society that places value on class, rank, and manners. Like the shônen worlds, the visual designs of the otome worlds are European. However, the period presented is later than the medieval setting of the shônen world, and the visual depiction is a pastiche of technology, architecture, and dress that occurred anywhere from the 1600s through the 1850 os (Figure 5). Like the protagonists in the shônen worlds, the real-world protagonists of the Otome gamic worlds can choose to follow the plot dictated by the game or choose an alternative plot that better meets their needs and desires.

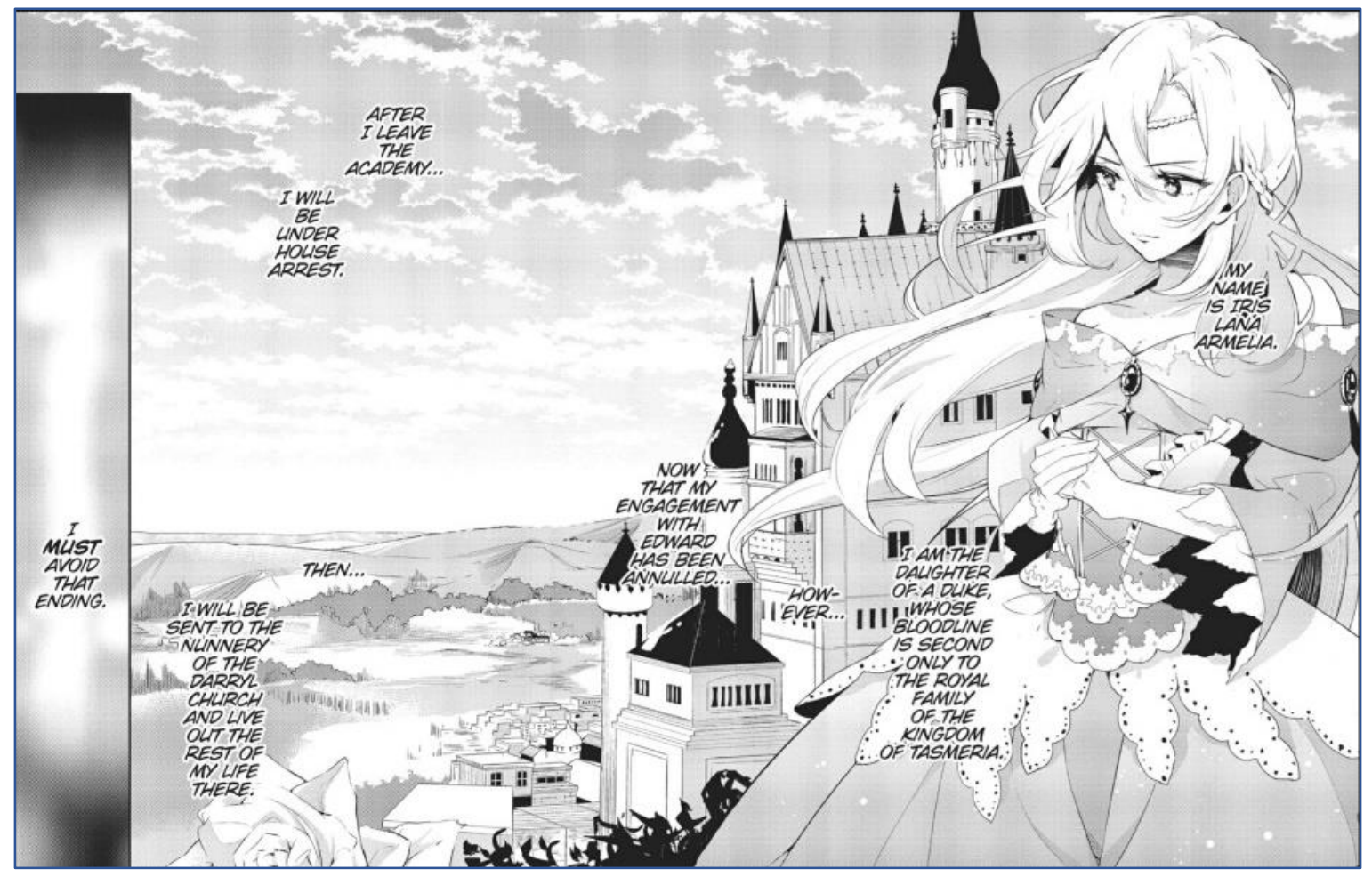

Figure 5. Iris from The Accomplishments of the Duke's Daughter 


\section{Gamic worlds}

Stories set in the shônen and otome worlds enjoy a rich intertextuality. The use of key tropes and visual cues in the beginning of a manga series conveys to the reader that the story is set in a "standard" gamic world. This allows the authors to freely use the various elements of the standard worlds with the expectation that they will be understood without explanation by the reader. In isekai manga, these worlds can be linked to actual games the protagonist (or the reader) is aware of or they can be generic "standard" game worlds. Elements of the games that routinely occur in these standard worlds include:

- Menus describing individual's characteristics (e.g., health points (HP), magic points (MP), specific skills, and levels);

- Adventure guilds (that manage small and large quests);

- Flags (pivotal events in the story that signal subsequent events);

- Opponents (monsters or evil individuals that must be defeated or out competed);

- Bosses (stronger than average opponents that mark transition points in a game);

- Targets (attractive men with hearts to be captured);

- Magical powers that are often linked to MP;

- Magic items (swords, armor, jewelry, etc.) that confer capabilities to the user;

- Spells;

- Familiars;

- Magical healing; and

- Storage bags that allow the player to carry any amount of weapons, food, water, money, or valuables. 
The concept of the "cheats" in isekai stories is borrowed from the mechanics of the coding of computer games. Normally roleplaying games require the player to spend considerable time completing tasks to grow and obtain necessary abilities. A cheat is a piece of code that allows the informed player to bypass this time and effort. With the cheat the player can more easily defeat opponents and advance in gameplay. The concept of a cheat is a redefinition of the idea of gifts or blessings awarded to characters based on grace or merit to advantages obtained by luck or craft and are, on some level, unfair.

The standard shônen and otome worlds are pastoral in nature and are a sharp contrast to the modern technological society of Japan. Information in modern societies largely resides outside of people (organizational knowledge, manuals, books, internet, etc.) and each individual typically understands only a part of the processes that go on around them. This leads to the disempowering of the individual. In contrast, the shônen and otome isekai operate on a human scale. Knowledge is held by people in the community. If it is not common knowledge, then it is known by a specialist (craftsperson, farmer, trader, or baker) who is a person in the community. Rare information is known by the king, priest, or mage who can be found in the kingdom's central town. The net result is that individuals, including the protagonist, are empowered in the isekai in a way that they are not in modern Japan or in any modern country.

\section{Mendlesohn's four story types and the gamic worlds}

All four of Mendlesohn's story types can be set in gamic worlds. Many of the stories are portal-quest stories including the four cited above for the shônen and otome gamic worlds. Surprisingly, computer roleplaying games in themselves are not portal-quest 
stories. They are immersive stories. The player as part of the initial steps of setting up the game resigns their humanity and becomes a player, who is perhaps inexperienced, but is a native of the isekai with no connection to the real world or to the player's life in the real world. Fictionalized versions of roleplaying games, therefore, tend to be immersive (e.g., Record of the Lodoss War) as well. More recently, stories have been created that: are set in gamic worlds, have a native protagonist, have a plot that differs from game play, and have no portal to the real world. These immersive stories are tagged as isekai. Such stories allow plots where the protagonist can have a richer backstory than in portal quests.

Invasive and liminal stories have also been developed using gamic worlds. Invasive stories have been created as extensions of the portal-quest plots. For example, a mangaka could create stories about what would happen if the summoned hero was sent back to the real world with his skills, powers, and cheats intact (The Hero Who Returned Remains the Strongest in the Modern World (2019, Isekaigaeri no Yuusha ga Gendai Saikyou!)), or what would happen if two summoners entered this world and compete to find and take the protagonist to the isekai (I am Both the Hero and the Demon King (2019, Boku ga Yuusha de Maou mo Boku de)). Liminal stories occur when the mangaka explores what would happen if the gamic isekai and real world overlapped to create spaces where humans and residents of the isekai interact (My Room Is a Dungeon Rest Stop (2017, Boku no Heya ga Dungeon no Kyuukeijo ni Natteshimatta Ken)).

In summary, isekai as a term referring to a literary genre of manga, anime, and light novels appears to have begun around 2013. Initially it was associated with portal-quest stories that involve a gamic world. ${ }^{19}$ Since that time, the isekai genre has been extended 
to include 1) all portal-quest fantasies created at any time, and 2) all immersive, invasion, and liminal stories that involve a gamic world. ${ }^{20}$

\section{Database narratives}

In 1989, Ôtsuka Eiji published a description of a media behavior he termed narrative consumption ${ }^{21}$. Narrative consumption is the act of reading small narratives not only for direct enjoyment but also as a way of accessing a grand narrative. A grand narrative is an overarching story that provides the framework for smaller stories and is only accessed by the consumption of the small narratives. The strategy of grand and multiple small narratives can be intentional when an author chooses to present a larger story in the form of a series of tales. Examples of this in literature include Yanagita Kunio's Tales of Tôno (1912, Tôno Monogatari22) and in Western speculative fiction Robert Silverberg's Majipoor series ${ }^{23}$ and Keith Roberts' Pavane. ${ }^{24}$ Grand narratives can also occur because an author's initial creation implies a larger narrative which is sufficiently attractive that it draws the original author ${ }^{25}$ and other authors back to tell other stories within that narrative. Examples of such grand narratives include Gundum and Slayers and the Western speculative media franchises of Marvel Universe, Star Wars, and Star Trek.

This model of reading multiple small narratives was extended by Azuma Hiroki²6 to instances where there are numerous small narratives with common character types, settings, and plots but where there is no grand narrative. Instead, the stories consist of collections of elements taken from a canonical pool recognizable by the reader. Azuma refers to this pool as the "grand nonnarrative" for the stories. These stories have no higher 
meaning other than that they are created with the elements and characteristics that come from the grand nonnarrative. Azuma further asserts that such grand nonnarratives consist of common plot elements that can be mixed and matched. The elements specify sets of common characters, and the characters can be in turn defined in terms of sets of common design elements (e.g., cat ears, blue hair, eye patches, and maid outfits). The result is that a small narrative can be considered to be a set of selections from a multitiered database.

Isekai manga appear to be an example of a collection of small narratives created from a grand nonnarrative. There is no grand narrative to isekai stories. Instead, the hundreds of individual stories follow a common set of plot points (e.g., life prior to entering the isekai, entering the isekai, the nature of the isekai, transformations of the protagonist, and motivations in the isekai) and only differ in the specifics of how the elements occur. The specifics are either taken from earlier isekai stories or are variants of earlier works. As a result, the reader of isekai stories has the expectation that plots, tropes, characters, and character designs will be drawn from a common tradition.

In this paper, we propose that a survey of the hundreds of portal-quest isekai manga series can identify the structure of plot elements, specific types of characters, and characteristics of these characters that make up the grand nonnarrative for isekai stories. This is done based on the basic plot structure of the portal-quest story, the empirical identification of regularly occurring elements, and the organization of the characteristics of the elements using a multitiered database. The individual manga series would then appear as a specific set of selections from the database. 


\section{Surveying English translations of isekai manga}

The appendix to this paper describes a survey that was performed on Englishtranslated isekai manga. The majority of the manga series are only partially available in English. This occurs for several reasons. Many manga series are either never completed due for flagging interest or are still ongoing. In addition, there is a lag in translation so that more recent chapters may not have been translated. Finally, translating groups may drop a series because of a lack of interest or resources. As a result, many series only have a few episodes available. Because of this bias in the available data, the survey could not investigate elements related to the outcome of the stories (e.g., did the protagonist return to the real world, or did they achieve their goals in the isekai). The scope of the survey, therefore, focuses on events and elements in the early portion of the stories.

The process of creating the survey is described in the appendix of this paper. A total of 1010 series from Japan, Korea, and China were identified by internet sites as "isekai stories". These series were briefly reviewed based on primary and secondary data. The manga series that had sufficient information were divided into the four categories of portal-quest, immersive, intrusion, and liminal. A second more detailed survey was performed on the 427 manga series identified as portal-quest isekai stories and where there were sufficient translated chapters to allow the survey to be performed. Focusing on portal-quest stories allowed the survey to assess the largest single block of stories with a relatively consistent plot. 
The survey instrument was developed by reading isekai manga and identifying story elements that occur in most of the stories and that have characteristics that vary across stories in a regular way. The questions in this survey fall into the following areas:

- Demographics and characteristics of the protagonist prior to entering the isekai;

- Method of entering the isekai;

- Characteristics of the isekai;

- Characteristics of the protagonist in the isekai (both physical, psychological, and social); and

- Interpersonal relationships in the isekai.

This survey focuses on the characteristics of the protagonist, however, data on other characters are also collected. These characters include the summoner (if summoned), others entering the isekai with the protagonist, divine agents, members of the opposite gender, and certain background characters in the isekai.

Once the survey design was finalized, the portal-quest manga were reread, and the survey was performed. Where possible, the answers to the questions were grouped into categories. For example, the age of the protagonist is defined using the categories of prehigh school, high school, college-age, adult, and elderly. The mechanisms for entering the isekai are organized into summoning, reincarnation, divine error, etc. A description of the survey instrument (questions and categories of responses) is given in a data dictionary provided as an ancillary file for this paper. 


\section{Findings from the survey}

The following are a partial set of findings from the survey. The complete results of the survey are available for download in the form of an Excel ${ }^{\mathrm{TM}}$ workbook. The survey found that portal-quest isekai manga can be organized in terms of a small number of elements and a limited number of ways the elements occur (categories of characteristics).

The chronology of events (but not necessarily the order of telling in a story) in portal-quest stories begins in the real world. As a result, the protagonists have various physical, psychological, and social characteristics prior to entering the isekai. The survey found that protagonists include women and men from junior high age to the elderly, but the largest group are adult males ( 41 percent). The ratio of male to female protagonists is 2.4 to 1 and the ratio of adult to teenage protagonists is 1.4 to 1 . Most of the protagonists have one or more negative elements in their lives (e.g., playing games to the detriment of schoolwork or a job, being bullied in school, being overworked at a job, suffering from mental or physical abuse at work or home, or being an invalid). Only eight percent are presented as either having a life characterized by positive elements or as being successful in their careers. Adult protagonists are sometimes identified in terms of their profession (doctor, scientist, lawyer, chef, pharmacist, etc.). These identifications typically become important for the subsequent events in the isekai.

The mechanisms for entering the isekai in the stories fall into six categories; "reincarnation," "divine act," "summoning," "specific tool," "pulled into game," and "no explanation". Reincarnation takes advantage of the fact that individuals living different lives in different worlds can have the same soul. As a result, the protagonist is a character 
in the isekai who simply remembers their past life in modern-day Japan. This is the gentlest method of entering the isekai and has the advantage of giving the protagonist a knowledge of the isekai, a family, personal connections, and a role in isekai society. A divine act occurs when a god, or god-like agent, causes the protagonist to enter the isekai. This method allows the protagonist to receive a blessing, or curse, that sets them apart from others. Summoning occurs when a character in the isekai pulls the protagonist into the isekai. Such acts establish a relationship between the summoner and the protagonist as the initial event in the isekai. Specific tools that transfer the protagonist to the isekai include magical items such as stones or jewels, doors, books, scrolls, or mirrors. They also can be religious shrines or technological devices such as spaceships, machines, or computers. The tools make the protagonist a victim and focus the plot on the tool and often the quest to return home. Being pulled into a game is a method that takes advantage of the ease of visualizing moving from playing a specific game to actually being in that game. These stories establish the protagonist as being knowable about the isekai and converts their success in gaming into a resource for life in the isekai. The method also satisfies the fantasy of never having to leave the game and returning to the real world. The final category is "no explanation". When there is no explanation for how the protagonist enters the isekai, the entering becomes part of the isekai and is a marvelous act. Such transitions provide the least explanation of the isekai (including how to return) and impose the least number of limitations on the actions of the protagonist. These mechanisms are not mutually exclusive. A goddess may act to reincarnate a person in the isekai as an infant with their memories intact or a god may intervene in a malicious summoning. 
The methods of entering the isekai differ in frequency and vary with the demographics of the protagonist. The characteristics ranked by frequency of occurrence from most to least common are summoning (28 percent), no explanation (23 percent), reincarnation (21 percent), divine act (20 percent), specific tool ( 8 percent), and pulled into game ( 8 percent). Stories with a teenage protagonist favor summoning but stories with adult protagonists do not. Reincarnation or no explanation are favored in stories with an adult female and divine act for stories with an adult male protagonist. Certain mechanisms require the protagonist to die (reincarnation and divine act) while others do not (summoning, pulled into game, and magic item). Adults (college age or older) of both genders have a higher probability of dying as part of entering the isekai than teenagers (high school age or younger).

In certain stories where the protagonist enters a shônen world via a divine act or by being summoned, the process of entering the isekai occurs in two steps. First, the protagonist leaves the real world and enters a liminal space (in the presence of the god or in a space where a summoning takes place). Key events occur in this space such as the awarding or revealing of gifts and the negotiation of the role of the protagonist in the isekai. Following these events, the protagonist truly enters the isekai and begins their journey.

About one in five stories has the protagonist enter the world as one of a group of individuals. Entering the world as a group is problematic. Unless the group had strong bonds prior to entering the isekai (close friends, a couple, a family, or a respected team) the protagonist almost always separates from the group shortly after entering the isekai. Summoning is also often a negative event. Of the 117 manga series where summoning 
occurs, about two thirds are either malicious (the summoner intends a bad outcome for the protagonist) or unintended (the protagonist is unwanted). Even when the summoning is positive, the protagonist typically rejects the purpose that they are summoned to perform. As a result, in only 6 percent of the summoning stories do the protagonists perform the tasks for which they were summoned.

The nature of the isekai in the vast majority ( 88 percent) of the surveyed manga series is based on specific roleplaying games or includes many of the game elements listed above. The largest fraction of the stories, 68 percent, are set in the standard shônen isekai, 15 percent in the standard otome isekai, and an additional five percent in isekais that differ from the two standard worlds but still include many of the game elements listed above. The remaining 12 percent of stories are split among isekai based on other types of computer games (e.g., dating sims or battle royals), non-gaming fantasy worlds, other planets, time travel, and entering dreams. As would be expected, 84 percent of protagonists entering the standard otome isekai are female and 83 percent entering the shônen isekai are male.

In the majority of stories (8o percent) the protagonist's body is changed. Protagonists take nonhuman forms in 15 percent of the stories. These include humanoids (e.g., orc, vampire, or elf), monsters (e.g., dragon or slime), animal (e.g., cat, dog, or bear), or objects (e.g., a wand, sword, or onsen). In 65 percent of the stories the protagonist remains human but is changed. These changes may be minimal (granting a magical power or making the individual a bit younger, thinner, or more athletic) or dramatic (changing gender or becoming an infant). Gender change occurs in seven percent of stories. When 
gender change occurs it is always involuntary, it occurs at similar rates for adults and teenagers, and 80 percent of the changes are from male to female.

The protagonist receives gifts/cheats upon arrival in the isekai in two thirds of the manga series. Beyond these gifts/cheats, protagonists have the advantage of the knowledge from a life in modern Japan in an isekai that is usually pre-industrial. In 14 percent of the stories, the protagonist enters a game known to the protagonist. In such cases, the protagonist has specific knowledge of the isekai's characteristics and in some cases future events in the isekai.

Once in the isekai, the protagonist's behavior is subject to external forces (finding food and shelter, avoiding threats, and negotiating life with isekai inhabitants). A small number of stories, seven percent, simply focus on survival; however, in the remainder of the stories the protagonist makes choices on how to live. In the computer games motivations are sometimes defined in terms of a quest, and in 20 percent of the isekai manga the protagonist adopts a quest. The more common motivation, however, is to fulfill personal desires that the protagonists bring with them from their lives in the real world. These include living an easy life (a life without stress, farm life, rural village life, or living in luxury) or achieving a personal goal (becoming the strongest magician, finding personal security, or creating a harem). These occur in 53 percent of the stories, and protagonists who were adults in the real world are motivated by personal desires more often than those who were teenagers. In five percent of the stories, the protagonists choose simply to help people. Three percent follow antisocial motivations such as becoming a sexual predator or enacting violent revenge. A larger fraction of male teenagers falls into this last category than adults or female teenagers. 
As discussed above, the great majority of protagonists enter the isekai alone, or if they enter with a group, they quickly separate. Once in the isekai, however, protagonists tend to form groups where they are the central individual. These groups are built by purchasing slaves, saving damsels, creating harems, and obtaining followers and teammates. Marriage is rare and when it occurs it is often polygamous. Food plays a prominent role in 18 percent of the stories. The protagonist may receive magic powers from eating certain foods, may have the power to create foods valued in the isekai, or may need to lose weight.

The protagonists are consistently heterosexual, and their views of the opposite gender are highly objectified. Male protagonists viewed females either as objects to be obtained (valued only in in terms of physical desirability) or as coplayers (valued only for their skills) in 78 percent of the stories. Female protagonists viewed males as objects or coplayers in 56 percent of the stories. The fraction of the stories where the first member of the other gender encountered in the isekai is sexually attractive is 81 percent for male protagonists and 64 percent for female protagonists. The other common views of the opposite gender are as nonromantic relationships (parent and child, leader and follower, friend, or sibling). Romantic views of the other gender occurred in one percent of male protagonist stories and ten percent of the female protagonist stories.

\section{Discussion}

This project was able to identify a 1010 isekai series. Using the concepts of the portal-quest category, 427 manga series are identified that have similar storylines in which consistent elements could be readily identified. In recent years isekai manga have 
been dominated by two distinct types of gamic stories (shônen and otome). These types of stories are based on two types of computer role playing games, a dungeons-anddragons-based shônen adventure games and a dating-simulation-based otome romance games. The large numbers of these stories allowed the creation of a survey instrument that collected information on the frequency of common approaches to story elements such as plot points, characters, and the characteristics of the characters. The results of the survey form a multitiered database that appears to be an example of Azuma's grand nonnarrative.

The success of this exercise does not imply that an actual database exists or that such a database was used to generate the isekai manga included in the survey. Rather, it points to the existence of social and economic forces in the writing and publishing of manga that create such a pattern. ${ }^{27,}{ }^{28}$ The plot of portal-quest isekai manga is narrowly defined and forces stories to contain the same elements. The mangaka and their editors must master the conflicting needs for continuity and novelty in each new publication. A successful manga begets imitations, but over the long run imitation without novelty is unlikely to maintain large numbers of readers. Hence one story about players being trapped in an isekai focuses on the quest to escape, Sword Art Online, and a second story of players trapped in a game, Log Horizon, on the movement of individuals from characters in a game to members in an actual society. If stories of a doctor's or pharmacist's next life in an isekai prove popular, then stories where the protagonist is a lawyer or veterinarian are created. This leads to the identification of story elements where variation leads to novelty and desirable affects, but which do not violate the readers' expectations for an isekai story. Once these points are identified, authors can mine the 
variables for the generation of any number of new stories. The result, to paraphrase Lamarre, 29 is a "field of possible isekai stories" each created by the selection of the various elements of the story from approaches used in earlier stories or logical extensions of such approaches.

The resulting patterns of the elements in such stores behave as if they are a product of a mechanical sampling of a database (the grand nonnarrative) and which retroactively can be captured in an actual database. This ability to maintain a common formula but vary superficial aspects of the story also leads to the hallmarks of isekai manga that the stories are the same, the characters are stock, and the affects of the story are identical.

While computer games have a tremendous influence on isekai stories, the stories usually subvert traditional games' storylines rather than simply repeating them. Instead of entering a game as a wish fulfillment, the act of entering is a deadly trap (Sword Art Online). Instead of a kingdom desperately needing to be saved from a horrible fate, you have deceitful and untrustworthy summoners demanding that you risk your life in a very uncertain endeavor (The Golden Word Master - the Four Heroes and the Innocent Bystander with the Unique Cheat, (2014), Konjiki no Moji Tsukai - Yuusha Yonin ni Makikomareta Unique Cheat). Instead of taking the role of the beautiful but underdog protagonist of an otome game, you are reincarnated as the villainess of the story (My Next Life as a Villainess: All Routes Lead to Doom! (2017), Otome gèmu no hametsu furagu shika nai akuyaku reijō ni tensei shite shimatta...), a toady in the villainess's entourage (I'm Thinking of Quitting the Villainess' Entourage (2019), Akuyaku reijō no torimaki yameyou to omoimasu), or a relative of a villain (I Am Troubled That My Fiancé Is a Villain (2018), Fianse ga akuyaku de komattemasu). 
In addition to subverting plots, the stories subvert the basic assumptions of the standard game worlds. What if the humans led by the hero are violent racists intent on the extermination of innocent members of other races and species? What if neither magic nor martial arts are the way to success, but rather the skills of the salaryman (political acumen, organizational skills, and ability to tactfully negotiate)? What if the prince of a kingdom is likely to be a poor husband?

The preference for personal goals over being the "hero" in the shônen world and becoming the villainess rather than the heroine in the otome world are a rejection of the definitions of success established by the roleplaying games. In both cases, the protagonists receive lives that allow more freedom from the expectations of isekai society. These roles require that the protagonist be more responsible for themselves but also allow the protagonist to personally reap the benefits of their efforts. In addition, the protagonists in certain stories negotiate their roles with the divine agent or summoner instead of passively accepting them. In these stories the goal of the protagonist is to assure that life in the isekai will meet their needs and will be better than their lives in the real world.

As a demonstration of how the survey results could be used in the study of isekai stories, data collected in the survey are used to determine if the age and gender of the protagonist in the real world predict differences in story characteristics. Such findings may have value in predicting the interests and perspectives of consumers of isekai manga if it is assumed that the demographics of the protagonist are a rough indicator for the demographics of the target market of isekai stories. 
This assumption is not meant to imply that protagonist demographics fully determine reader demographics for all manga or even all isekai manga. However, reader identification with the protagonist suggests that authors intending to target a specific demographic would both choose a protagonist similar to that of the target audience and select story elements known, or suspected to be, of interest to the target audience. Thus, protagonist demographics could serve as a marker for story elements chosen to attract specific demographics.

As discussed above, the survey results clearly show that protagonist demographics are correlated with the type of world in a manga (otome vs. shônen), how the world is entered, and the motivation of the protagonist in the isekai. Female readers are more likely to be attracted to stories set in otome worlds, and male readers to shônen worlds. Adults are more likely to see death as the only way to leave the real world and are more likely than teenagers to desire a live a life of ease. Teenagers expect to be summoned but are suspicious of the summoners. These patterns suggest that adults are more pessimistic and modest in their desires then teenagers, and that fans of all ages see themselves as being oppressed by the real world. For the fans of isekai stories the goal in entering the isekai is to achieve redemption, or liberation, from life in the real world. Few of the isekai protagonists show much interest in returning home.

These findings are not implausible predictions of the readers' interests and views of the world. However, such conclusions should be tempered by the recognition that associations are not proof of causation. The characterization of the protagonists as having negative experiences in the real world can also simply be a tool of the mangaka to remove the protagonist's reluctance to fully embrace their new lives in the isekai. 


\section{Conclusion}

The findings presented in this paper are an initial attempt to mine the large number of isekai manga series that are either legally available or are available as fan scanlations for quantitative findings on the genre's characteristics. The effort shows that it is possible to extract and organize such data and to use the data to generate hypotheses about the audience of the stories and their interests. The paper demonstrated that the manga are highly influenced by role-playing games and show patterns of responses that appear to reflect the views and concerns of different demographics of readers. The survey results include many findings that are not included in this paper. The interested reader is encouraged to download and further analyze the database developed in this project. Finally, the approaches used here could be extended to look at other sets of manga. The survey instrument used here could be modified and applied to the other types of isekai manga (intrusion, immersive, and liminal) or could be applied to the isekai manhwa and manhua to investigate differences across countries.

\section{Acknowledgements}

The author wishes to thank the three anonymous reviewers for their comments on this paper. The comments greatly improved the paper and the design of the database. 


\section{Appendix: Design of the survey of isekai manga}

The survey of isekai manga was performed on data collected from internet sources between January 2019 to June 2020. The survey used information collected from five internet sites. Four of these sites provided access to existing databases that contained data on individual manga series (Baka-Updates - Manga Division (https://www.mangaupdates.com/index.html), Anime-Planet (https://www.animeplanet.com/), Anime News Network -Encyclopedia (https://www.animenewsnetwork.com/), and Manga Rock (https://mangarock.com/). The remaining site, Kissmanga, was a scanlation aggregator site which provided access to the actual scanlations. This site was shut down in late 2020 but the scanlations remain available from other aggregator sites. Each of the five sites contained lists of manga series that were identified by the site as isekai stories. These series came from Korea and China as well as Japan. Two of the sites, Baka-updates and Anime-Planet, included information on manga series that have not been translated to English.

The set of manga series that were surveyed was developed using the following process. An initial set of series identified as isekai in one or more of the five internet sites were collected. The list of works identified as isekai is not consistent from site to site. As a result, while each site listed between 400 and 600 series, a total of 1010 unique series were identified from the sites. Each of the series was investigated to confirm the national origin of the work, the availability of the text, and where possible the category of the work as defined by Mendlesohn ${ }^{30}$ (portal-quest, immersive, intrusion, or liminal). 
The purpose of the survey is to investigate isekai manga. As a result, works from China and Korea are excluded (264 series). Of the remaining 746 manga series, 560 had sufficient portions translated so that the survey could be performed. Manga series that consist of "one-shots" (i.e., single independent stories) are not included in the survey since they do not provide sufficient information to perform the survey. In addition, certain manga series are spinoffs or sequels of existing manga and have a common protagonist and setting. When this occurs, only the initial manga series is included in the survey. Of the 560 series, 427 are portal-quests, 55 were immersive, 48 were intrusion, and 30 were liminal. As a result, the 427 manga represent the single largest block of manga that can be described by a relatively consistent plot. These manga formed the data frame for the study.

The data set for the survey is defined by the availability of translated manga. The largest possible data set for this effort would be the set of all published isekai manga series. Such a data set would reflect the interests and backgrounds of Japanese isekai manga readers. This study did not have access to such data. Instead, the five sites provide potentially biased samples of the published manga series. These data are potentially biased by what manga series are available to scanlation teams and which manga series the teams chose to translate. As discussed above, Baka-Updates - Manga Division and Anime-Planet include data on series that have not been translated. Based on data from these two sites, it appears that about three-fourths of the isekai stores (as identified by the sites) have at least one translated chapter. A comparison of the untranslated manga to the translated manga was performed based on the English summaries of the manga. Untranslated manga were 97 percent portal-quest stories and 
three percent immersive. Translated manga were 76 percent portal-quest, ten percent immersive, five percent liminal, and nine percent intrusion. This finding suggests the untranslated manga are also dominated by portal-quest stories.

Because of the use of data from multiple sites, the 427 manga series are believed to be a reasonably complete census of the available English-translated portal-quest isekai manga series as of June 2020. As a result, uncertainties in the findings due to sampling error are not investigated.

The stories listed by the five sites included in this survey have various levels of erotic content but do not include hentai manga (manga that prioritize explicit sexual content). Hentai isekai manga are typically limited to a single issue and do not include information on the elements included in the survey. As a result, while the survey does include manga series with erotic content it does not include hentai manga series.

The use of scanlated material in this study is not desirable since the author is reluctant to give attention to materials that violate the copyrights of the owners. In addition, the uneven quality of the translations from scanlators is likely to introduce uncertainty in the answers to survey questions. However, a review of the manga legally available in English found that fewer than 80 isekai series are currently available. ${ }^{31}$ Limiting this survey to those manga series would greatly reduce the quality and power of the survey.

Electronic copies of the data dictionary for the survey and the raw survey data (in the form of an Excel ${ }^{\mathrm{TH}}$ workbook (.xlsx) and in two comma separated values files (.csv)) are available for download from JAMS. 
Notes:

${ }^{1}$ Anime planet (https://www.anime-planet.com/) Accessed April 2020.

2 Ibid.

3 Ibid.

4 Azuma, Hiroki. Dôbutsu-ka suru posuto modan: Otaku kara mita Nihon shakai 2001.

Translated by Jonathan E Able and Shion Kono as Otaku: Japan's Database Animals (U of Minnesota Press, 2009.) 30-35

5 Csicsery-Ronay, Istvan. The Seven Beauties of Science Fiction. Wesleyan University Press, 2012.

13

${ }^{6}$ Csicsery-Ronay, Istvan. The Seven Beauties of Science Fiction. 82

${ }^{7}$ https://trends.google.com/trends/?geo=US Accessed June 15, 2021

8 Ibid.

9 Alexander, Lloyd. "High Fantasy and Heroic Romance." The Horn Book Magazine 47 (1971): 577-584.

${ }^{10}$ Todorov, Tzvetan, and TSvetan Todorov. The Fantastic: A Structural Approach to a Literary

Genre. Cornell University Press, 1975. 41-57

${ }^{11}$ Mendlesohn, Farah. Rhetorics of Fantasy. Wesleyan University Press, 2014. xviii - xxiv

12 Todorov. The Fantastic: A Structural Approach to a Literary Genre. and Jackson, Rosemary.

Fantasy: The Literature of Subversion. London and New, 1998.

13 Mendlesohn, Rhetorics of Fantasy. xviii - xxiv

14 Steinberg, Marc. "8-Bit Manga: Kadokawa's Madara, or, The Gameic Media Mix"

Kinephanos: Journal of Media Studies and Popular Culture 5 (2015): 44.

${ }^{15}$ Sword Art Online and Log Horizon both began as light novels before appearing as manga. Isekai stores frequently occur as light novels before becoming manga and it has been argued that the isekai genre is predominately a category of light novels rather than anime or manga.

16 Ewalt, David. Of dice and men: The story of Dungeons \& Dragons and the people who play it.

Simon and Schuster, 2013.

17 Barton, Matt, and Shane Stacks. Dungeons and Desktops: The History of Computer Role-

Playing Games 2e. CRC Press, 2019.

${ }^{18}$ Aranda, Oscar García. "Representations of Europe in Japanese anime: An overview of case studies and theoretical frameworks." Mutual Images Journal 8 (2020): 47-84.

${ }_{19}$ Example definitions of isekai are given at the following sites. All sites were accessed June 15, 2020.

https://en.wikipedia.org/wiki/Isekai

https://www.urbandictionary.com/define.php?term=isekai

https://www.definitions.net/definition/isekai

https://www.anime-planet.com/anime/tags/isekai

https://tvtropes.org/pmwiki/pmwiki.php/Main/TrappedInAnotherWorld

20 https://www.animenewsnetwork.com/the-mike-toole-show/2019-01-21/.142332 Accessed

July 31,2021

${ }^{21}$ Ôtsuka, Eiji, and Steinberg, Marc. "World and Variation: The Reproduction and Consumption

of Narrative." Mechademia, (2010) 5(1), 99-116.

22 Yanagita, Kunio. Tono Monogatari. Kadokawa Shoten. Tokyo: Chiyoda (1910, Tales of Tono).

23 http://www.isfdb.org/cgi-bin/ea.cgi?54 accessed June 15, 2020

24 Roberts, Keith. Pavane. Old Earth Books, 2011.

25 A literary expression of this is "Leaf by Niggle" in Tolkien, John Ronald Reuel. Tree and Leaf;

Smith of Wootton Major; The Homecoming of Beorhtnoth, Beorhthelm's Son. Unwin Books, 1975.

${ }^{26}$ Azuma, Otaku: Japan's Database Animals. 30-35 
${ }_{27}$ Perdijk, Paul. "Database Consumption.” Japanese Media and Popular Culture: An Open-Access Digital Initiative of the University of Tokyo. https://jmpc-utokyo.com/keyword/database-consumption/. Accessed June 1, 2020.

${ }^{28}$ Condry, Ian. The Soul of Anime: Collaborative Creativity and Japan's Media Success Story. Duke University Press, 2013. 100-102

29 Lamarre, Thomas. The Anime Machine: A Media Theory of Animation. U of Minnesota Press, 2009. 259

30 Mendlesohn, Rhetorics of Fantasy. xviii - xxiv

${ }^{11}$ Amazon (https://www.amazon.com/) was searched using the terms isekai, manga, "Volume 1", and -"light novel" on June 16, 2020. Bookwalker (https://global.bookwalker.jp/) was searched for isekai manga series available in English on June 16, 2020. In both cases less than 80 series were reported as being available. 


\section{Bibliography}

Alexander, Lloyd. "High Fantasy and Heroic Romance." The Horn Book Magazine 47 (1971): 577-584.

Azuma, Hiroki. Dôbutsu-ka suru posuto modan: Otaku kara mita Nihon shakai 2001. Translated by Jonathan E Able and Shion Kono as Otaku: Japan's Database Animals (U of Minnesota Press, 2009.) 30-35

Clements, Jonathan, and Helen McCarthy. The Anime Encyclopedia: A Century of Japanese Animation. Stone Bridge Press, 2015.

Csicsery-Ronay, Istvan. The Seven Beauties of Science Fiction. Wesleyan University Press, 2012. 82 (1998).

Jackson, Rosemary. Fantasy: The Literature of Subversion. London and New

Lamarre, Thomas. The Anime Machine: A Media Theory of Animation. U of Minnesota Press, 2009. 259

Mendlesohn, Farah. Rhetorics of Fantasy. Wesleyan University Press, 2014. xviii xxiv

Ôtsuka, Eiji, and Steinberg, Marc (2010). "World and Variation: The Reproduction and Consumption of Narrative”. Mechademia, 5(1), 99-116.

Steinberg, Marc. "8-Bit Manga: Kadokawa's Madara, or The Gameic Media Mix" Kinephanos: Journal of Media Studies and Popular Culture 5 (2015): 44.

Todorov, Tzvetan, and TSvetan Todorov. The Fantastic: A Structural Approach to a Literary Genre. Cornell University Press, 1975. 41-57 